J. Lake Sci. (湖泊科学), 2011, 23(2): 196-202

http: //www.jlakes.org. E-mail : jlakes@niglas.ac.cn

(c) 2011 by Journal of Lake Sciences

\title{
兴凯湖水环境状况及其保护对策”
}

\author{
朴德雄 ${ }^{1}$, 王风昆 ${ }^{2}$ \\ $(1:$ 鸡西市环境监测站, 鸡西 158100$)$ \\ ( 2 : 鸡西市环境保护局, 鸡西 158300$)$
}

\begin{abstract}
摘 要: 兴凯湖是中、俄界湖. 监测统计数据显示, $1994-1998$ 年, 大兴凯湖 $\mathrm{COD}_{\mathrm{Mn}}$ 为 $5.42 \mathrm{mg} / \mathrm{L}, \mathrm{BOD}_{5}$ 为 $1.59-2.91 \mathrm{mg} / \mathrm{L}$, $\mathrm{TP}$ 为 $0.35 \mathrm{mg} / \mathrm{L}$, 已达中-富营养水平;2009 年监测报告显示, 大兴凯湖 $\mathrm{COD}_{\mathrm{Mn}}$ 平均为 $4.09 \mathrm{mg} / \mathrm{L}$, 氨氮平均值为 $0.466 \mathrm{mg} / \mathrm{L}$, 水质由 II 类标准下降到 III类, 有进一步退化趋势. 俄罗斯阿斯特拉罕段面监测数据显示, 2005-2009 年, 兴凯湖污染主要 为有机物污染, $\mathrm{COD}_{\mathrm{Mn}}$ 为 $11.5-16.2 \mathrm{mg} / \mathrm{L}$, TP 为 $0.046-0.266 \mathrm{mg} / \mathrm{L}$. 数据表明, 湖水水质降低, 并有一定的富营养化趋 势. 来自兴凯湖流域城市和工、农业生产以及旅游业污水对湖泊水环境产生了影响, 水环境安全形势面临一定压力. 本文 分析兴凯湖水环境面临的威胁,并提出水环境保护措施.
\end{abstract}

关键词: 水环境;污染防治;兴凯湖

\section{Environmental conditions and the protection countermeasures for waters of Lake Xingkai}

PIAO Dexiong ${ }^{1} \&$ WANG Fengkun ${ }^{2}$

(1: Environmental Monitoring Center, Jixi 158100, P. R. China)

(2: Environmental Protection Bureau, Jixi 158300 , P. R. China)

Abstract: Lake Xingkai is a boundary lake between China and Russia. Based on monitoring and statistical data in the Big Lake Xingkai, the average value of $\mathrm{COD}_{\mathrm{Mn}}$ was $5.42 \mathrm{mg} / \mathrm{L}, \mathrm{BOD}_{5}$ was $1.59-2.91 \mathrm{mg} / \mathrm{L}$, TP was $0.35 \mathrm{mg} / \mathrm{L}$ during the $1994-1998$ period, which was meso-eutrophic lake. Based on the monitoring report in the Big Lake Xingkai in 2009, the average value of $\mathrm{COD}_{\mathrm{Mn}}$ was $4.09 \mathrm{mg} / \mathrm{L}$, the average of $\mathrm{NH}_{4}-\mathrm{N}$ was $0.466 \mathrm{mg} / \mathrm{L}$. The water quality standard decreased from Grade II to Grade III and was further degraded. During the 2005 -2009 period based on monitoring data from Astrakhanka of Russia, the major pollution was organic pollutants, in which $\mathrm{COD}_{\mathrm{Mn}}$ was $11.5-16.2 \mathrm{mg} / \mathrm{L}$ and TP was $0.046-0.266 \mathrm{mg} / \mathrm{L}$. The results indicated that water quality was deteriorated and had eutrophication tendency. The industrial and tourism sewage seriously influenced on water environment, and the water environment safety faces certain pressures. This article analyzed the threats and provided the feasibility countermeasures for protecting waters of Lake Xingkai.

Keywords: Water environments; pollution control; Lake Xingkai

湖泊是陆地水圈的重要组成部分, 其生态健康与安全是我国社会经济发展的重要保障. 湖泊污染和富 营养化是当今世界普遍关注的生态环境问题. 我国是一个多湖泊国家, 自 20 世纪 70 年代以来, 我国东部湖 泊污染和富营养化加剧, 21 世纪初, $75 \%$ 的湖泊达到富营养化程度, $80 \%$ 以上湖泊受到污染 (水质 IV 类-劣 V 类 ${ }^{[1]}$. 我国南方太湖、巢湖、滇池等大型天然湖泊大面积水华, 特别是 2007 年无锡太湖蓝藻水华导致饮用 水危机,湖泊污染和富营养化成为我国重要的生态环境问题 ${ }^{[2]}$.

兴凯湖素称“三江平原基因库”, 有湖泊、沼泽、森林、草甸等多样植被类型, 不仅创造了巨大的防洪、灌 溉、水产养殖和景观旅游价值, 还发挥着净化水质、调节气候等特殊生态功能 ${ }^{\left[{ }^{3}\right]}$. 作为中俄共有的国际性水 域, 兴凯湖流域不但是两国重要粮食产区 ${ }^{[4]}$, 也是东北亚重要水禽繁殖地和迁徙通道, 生物多样性热点保护 地区 ${ }^{[5-7]} .1996$ 年, 中俄两国政府签署《兴凯湖保护区协定》, 将兴凯湖流域内的两个国家级保护区列人国际 重要湿地和世界生物圈保护区. 兴凯湖和松阿察河涉及中俄水资源分配和水体保护等多方面问题,在当前

* 2010-01-26 收稿;2010-06-24 收修改稿. 朴德雄,男,1967 年生,学士,工程师;E-mail: bhqwfk@ 126. com. 
人类活动干扰日益加强的境况下, 如何保留 “一湖清水”, 既是生态环境问题, 也是政治经济问题, 涉及国际 水域安全稳定,关系流域人类生存和发展.

兴凯湖水质监测方面的材料公布得很少, 虽然黑龙江省密山市环境监测站开展兴凯湖水质监测多年, 但有关监测数据及湖区生态环境状况资料均未公布,中方对俄罗斯环保专家研究兴凯湖水质的文章了解的 有限. 本文利用从事兴凯湖保护区、兴凯湖环境保护工作及对俄合作的机会, 对所收集到的中俄有关兴凯湖 水环境资料进行了归纳和总结, 提出了一些兴凯湖水环境保护方面的建议.

\section{1 研究区概况}

兴凯湖位于东北三江平原南部, 属于地堑式断陷湖, 是东北亚最大的淡水湖. 该流域 $\left(43^{\circ} 55^{\prime}-46^{\circ} 30^{\prime} \mathrm{N}\right.$, $131^{\circ} 25^{\prime}-134^{\circ} 20^{\prime} \mathrm{E}$ ) 是由穆棱河、兴凯湖和乌苏里江共同作用形成的低平原 (断陷盆地), 其西南、西部和东 部分别为我国的老爷岭、完达山和俄罗斯西尼山. 湖区西北高, 为山地丘陵; 东南低,为芦苇沼泽. 沿湖多遗 留古河道、牛轭湖, 碟形洼地密布, 地表径流滞缓, 内水不易外排. 湖区流域集水面积 $3.64 \times 10^{4} \mathrm{~km}^{2[8]}$, 多年 平均人湖水量约 $55.68 \times 10^{8} \mathrm{~m}^{3[9]}$. 湖区多年降水量 $530-600 \mathrm{~mm}$, 多年平均蒸发量 $636-755 \mathrm{~mm}$. 兴凯湖每年 11 月一次年 3 月为冰封期 (枯水期), 冰层厚度 $0.8-1.5 \mathrm{~m} ; 7-9$ 月为丰水期 ${ }^{[11]}$. 湖区常年盛行西风,年均风 速 $3.3 \mathrm{~m} / \mathrm{s}$, 春、夏季多西南风,秋、冬季多西北风. 受巨大水体作用,形成了本区特有小气候: 春季气温比周边 地区低 $1-3^{\circ} \mathrm{C}$, 秋季无霜期比内陆同纬度地区约晚 $15 \mathrm{~d}$.

兴凯湖 $\left(45^{\circ} 0^{\prime} \mathrm{N}, 132^{\circ} 25^{\prime} \mathrm{E}\right.$, 图 1) 有 20 多条中、小河流注人, 又接纳穆棱河大部分来水,下游以松阿察 河、乌苏里江与黑龙江相通 ${ }^{[10]}$. 兴凯湖由大、小两湖组成, 中间有天然沙岗, 上有 3 座人工水闸相通. 大兴凯 湖呈椭圆形, 北宽南窄, 总面积 $4190 \mathrm{~km}^{2}$, 大致以西部白棱河口至东部松阿察河口连线为中俄界线, 北部水域 $1160 \mathrm{~km}^{2}$ 属于我国. 湖面海拔 $69.15 \mathrm{~m}$, 平均水深 $3.5 \mathrm{~m}$, 蓄水量 $183 \times 10^{8} \mathrm{~m}^{3[11-12]} .1984-2009$ 年俄罗斯阿斯特 拉罕监测站在大兴凯湖中部水域监测显示, 多年水位变幅不大, 自 2000 年以来, 湖水呈高位之势 ( 俄罗斯以 波罗的海水系海拔 66m 水准面作为湖泊水位变化零起点, 1965 年) (图 2). 大兴凯湖底浅碟状,湖床缓斜坡, 形成大面积湖岸浅滩, 湖水有潮汐现象, 湖面风浪较大, 无风时浪高 $0.3 \mathrm{~m}$, 有风时浪高 $0.7 \mathrm{~m}$, 泥沙质湖底受 风浪和湖流作用, 经常处于不稳定状态, 悬浮物导致近岸水体浑浊. 在水动力作用下, 底部泥沙悬浮会明显 造成水体总磷 (TP) 、总氮 (TN) 和悬浮物 (SS) 浓度快速上升, 内源释放加大. 小兴凯湖为相对封闭的内湖, 呈 “牛轭” 状, 面积 $176 \mathrm{~km}^{2}$, 海拔 $70.28 \mathrm{~m}$, 平均水深 $1.8 \mathrm{~m}$, 蓄水量 $3.3 \times 10^{8} \mathrm{~m}^{3}$. 湖中水生植物丛生, 风浪小. 松阿 察河为中俄界河、兴凯湖唯一出水口、乌苏里江左源, 全长 $208.5 \mathrm{~km}$, 流域面积 $4100 \mathrm{~km}^{2}$, 河道迂曲, 支流众 多, 水深流急, 干流几乎常年不冻. 根据松阿察河河口人流流量 $66.03 \mathrm{~m}^{3} / \mathrm{s}$ 计算 ${ }^{[13]}$, 松阿察河泄水量多年平 均为 $20.8 \times 10^{8} \mathrm{~m}^{3}$, 则兴凯湖换水周期为 $8.8 \mathrm{a}$.

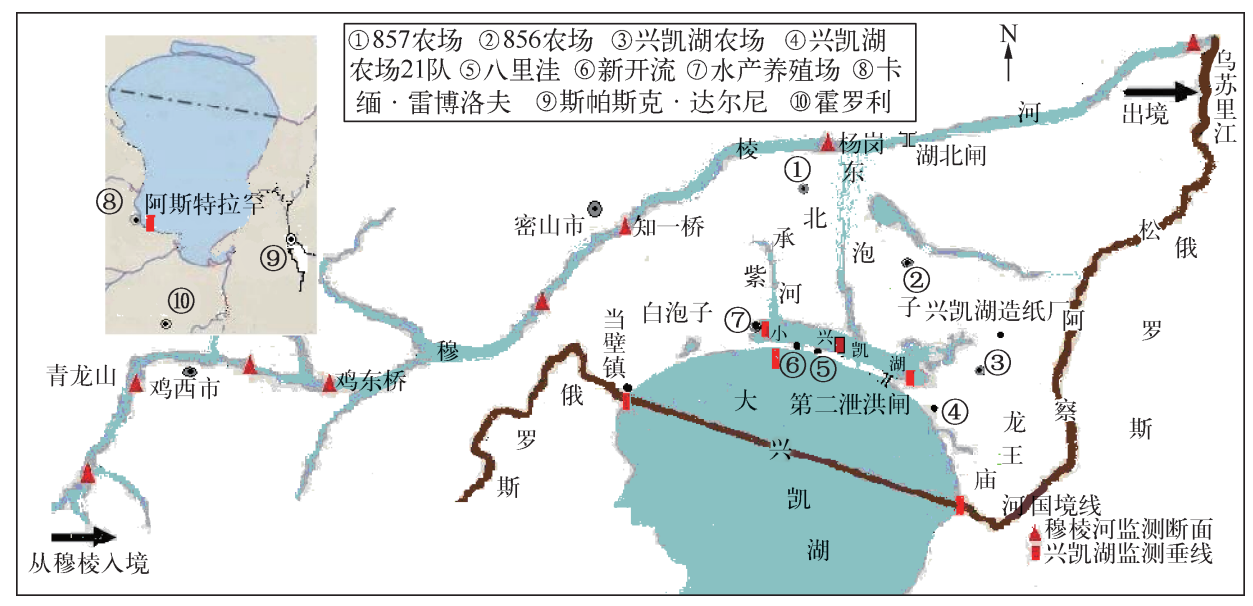

图 1 兴凯湖水体监测示意图

Fig. 1 Water monitoring of Lake Xingkai 


\section{2 监测方法和数据来源}

1979 年我国开始兴凯湖水体监测, 1999 年将兴凯湖纳人国家环境监测管理区域. 2009 年, 黑龙江省鸡 西市环境监测站接替密山市环境监测站对大、小兴凯湖开始全面监测, 监测项目从 18 个扩大到 28 个. 黑龙 江省鸡西市环境监测站,在兴凯湖每年布设 6 条垂线 (大、小兴凯湖各 3 条)和穆棱河 8 处监测断面 (图 1 ), 采样点距岸边 $100 \mathrm{~m}$ 之内, 水面以下 $20-50 \mathrm{~cm}$, 采集水样 8 次 (1、2、5-10 月), 对水体 $\mathrm{pH} 、 \mathrm{SS} 、$ 硬度、COD、 $\mathrm{BOD}_{5}$ 、氨氮 $\left(\mathrm{NH}_{4}-\mathrm{N}\right)$ 等水质项目进行监测. 样品依据国家环境有关技术规范进行分析, 大、小兴凯湖和穆棱 河各监测点分别执行《国家地面水环境质量标准》( GB3838-2002).

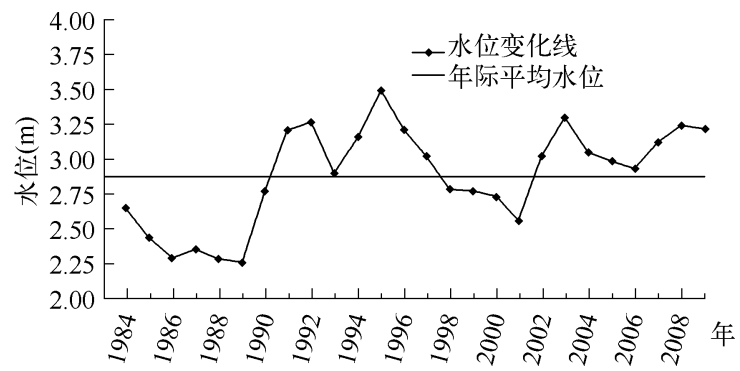

图 2 兴凯湖多年水位变化

Fig. 2 Water-level fluctuation of Lake Xingkai for years

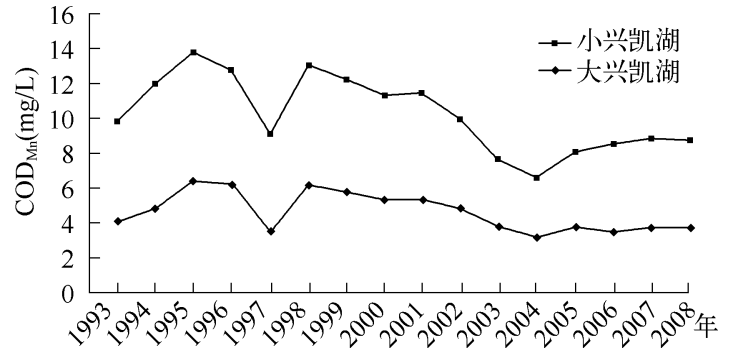

图 3 大、小兴凯湖高锰酸盐指数变化 $(1993-2008$ 年 $)$

Fig. $3 \mathrm{COD}_{\mathrm{Mn}}$ changes in the Big Lake Xingkai and Small Lake Xingkai (1993-2008)

俄方于 1952 年在阿斯特拉罕断面开始监测兴凯湖水质状况, 1976 年并人国家水污染常规监测网, 1985 年开始常规监测大湖水质. 中俄跨界水体联合监测从 2007 年开始.

本文资料来源有二:一是黑龙江省密山市和鸡西市环境监测站、俄罗斯滨海边疆区环境监测站监测数 据, 二是兴凯湖国家级自然保护区及俄汉喀斯基国家自然保护区资料库文献. 在搜集材料时采用了实地调 查、采访、分析、比较等方法.

\section{3 结果分析}

\section{1 水环境状况}

3. 1.1 中国境内 兴凯湖水质监测数据显示: 1994-1998 年, 大、小兴凯湖 $\mathrm{pH}$ 为 7.0-7.53, $\mathrm{COD}_{\mathrm{Mn}}$ 平均值分 别为 $5.42 \mathrm{mg} / \mathrm{L}$ 和 $6.65 \mathrm{mg} / \mathrm{L}$, 呈波形升势; $\mathrm{BOD}_{5}$ 分别为 $1.59-2.91 \mathrm{mg} / \mathrm{L}$ 和 $1.76-3.20 \mathrm{mg} / \mathrm{L}$, 亦呈波形升 势. TP 值分别为 $0.013-0.049 \mathrm{mg} / \mathrm{L}$ 和 $0.013-0.071 \mathrm{mg} / \mathrm{L}, \mathrm{TN}$ 变幅为 $0.0876-2.65 \mathrm{mg} / \mathrm{L}$, 平均 $0.969 \mathrm{mg} / \mathrm{L}$, 磷酸盐 $0.143-0.196 \mathrm{mg} / \mathrm{L}^{[14]}$, 已达中一富营养水平. 溶解氧 DO 在 $8-12 \mathrm{mg} / \mathrm{L}$ 之间, 饱和度大于 $90 \% .21$ 世 纪初前 5 年高锰酸盐指数浓度有所下降, 后 3 年开始上升, 大兴凯湖 $\mathrm{NH}_{4}-\mathrm{N}$ 含量增加. 鸡西市环境质量 2009 年报告资料显示, 大兴凯湖 $\mathrm{COD}_{\mathrm{Mn}}$ 平均值 $4.09 \mathrm{mg} / \mathrm{L}$ (最大值 $5.08 \mathrm{mg} / \mathrm{L}$ ), 超标率 $41.7 \% ; \mathrm{NH}_{4}-\mathrm{N}$ 平均值为 $0.466 \mathrm{mg} / \mathrm{L}$ (最大值 $0.626 \mathrm{mg} / \mathrm{L}$ ), 超标率 $29.2 \%$; 水质由 II 类标准下降到 III 类, 贫级富营养化水平, 主要污染 指标为 $\mathrm{COD}_{\mathrm{Mn}}$. 小兴凯湖水质已达国家地表水 III类标准, $\mathrm{COD}_{\mathrm{Mn}}$ 平均值为 $4.73 \mathrm{mg} / \mathrm{L}$ (最大为 $6.40 \mathrm{mg} / \mathrm{L}$ ), 超标 率12.5\% (图3). 东北林业大学水生生物监测表明, 小兴凯湖蓝绿藻类占浮游植物的 $69 \%$, 藻类生物量 $31.35 \mathrm{mg} / \mathrm{L}$, 趋向中富营养水平(1).

3.1 .2 俄罗斯境内 在俄罗斯, 兴凯湖是远东地区最大的农业生产区 ${ }^{[13]}$ 和旅游休养中心, 随着远东地区经 济复苏, 环境问题与经济增长呈现出正相关性, 水环境污染和生态破坏加速. 流域内大的城市型居民点有卡 缅 - 雷勃洛夫、霍罗利、斯帕斯克 - 达尔尼等 6 个市、镇、区, 人口 25 万人, 集中了滨海边疆区 $47 \%$ 的农田, 主要工业有萤石、稀土、煤矿、水泥、石棉、建筑材料、食品加工厂等. 俄滨海边疆区环境监测站站长 $Г$. И. 谢梅

(1) 东北林业大学野生动物学院. 2010 年 8 月小兴凯湖水生生物监测报告. 2010 . 
金娜介绍 ${ }^{[15]}$, 兴凯湖污染主要为有机物污染, $\mathrm{COD}_{\mathrm{Mn}}$ 为 $11.5-16.2 \mathrm{mg} / \mathrm{L}$, TP 为 $0.046-$ $0.266 \mathrm{mg} / \mathrm{L}$ (表 1 ). 氮、磷等有机物导致水体 富营养化加重, 湖水混浊度和悬浮物浓度高, 流域水体中铁含量大. 20 世纪中叶,俄方开发 灌溉农田 $790 \mathrm{~km}^{2}, 20$ 世纪六、七十年代, 工业 生产污染量加大, 居民生活污水排放量增多, 上游集水区急增的农田回水携带农药、化肥残 留严重威胁水体生态系统. 80 年代中叶, 俄 $308 \mathrm{~km}$ 环大湖沿岸区已有 $160 \mathrm{~km}$ 改造成水田 灌溉系统, 成为威胁兴凯湖生态质量的主要因 素. $1986-1989$ 年间除草剂、杀虫剂大量施 用. 在 20 世纪 80 年代末 90 年代初, 大湖周边 农业污染剧增与湖水自然减少并行, 造成了湖 水高强度有机物污染. 1988 年滴滴涕 (DDT) 及其代谢物总量超过了国家标量 60-70 倍. 直到 1990s 后期, 由于水稻田急剧减少, 杀虫 剂用量才开始下降. 在近 5 年湖水污染物中石 油类和挥发酚平均含量分别超过国家指标的 1.2-2. 4 倍和 $2-3$ 倍. 但六氯化苯 (六六六) 的年均含量开始低于国家标量, 滴滴涕代谢物 总量达到 $0.001 \mathrm{mg} / \mathrm{L}$. 在随后的 10 年间, 随着 水田面积的缩减和大湖水体水位的回升趋势, 湖水自净能力得以增强, 湖水有机物污染出现 了下降趋势. 1996-2009 年, 卡缅・雷勃洛夫 地区湖水 $\mathrm{Cu}$ 污染指数最大富集量都超过国 标( > 30 国标 $1 \mu \mathrm{g} / \mathrm{L}$ ) (图 4), 其他重金属污 染中, 发现有 $\mathrm{Zn} 、 \mathrm{Al} 、 \mathrm{Mn}$ 和 $\mathrm{Cd}$, 整个监测过程 中兴凯湖及其人湖河流的石油类污染非常高, 有 $50 \%$ 的样品超标. 水文化学和水文生物指 标显示, 兴凯湖已属中度污染型湖泊 (表 2). 随着远东地区农业复垦政策的出台,农业面源 污染呈急剧上升,水体富营养化有加剧趋势.

\section{2 有机污染物的生物体富集状况}

$1986-1987$ 年俄罗斯科学院远东分院太

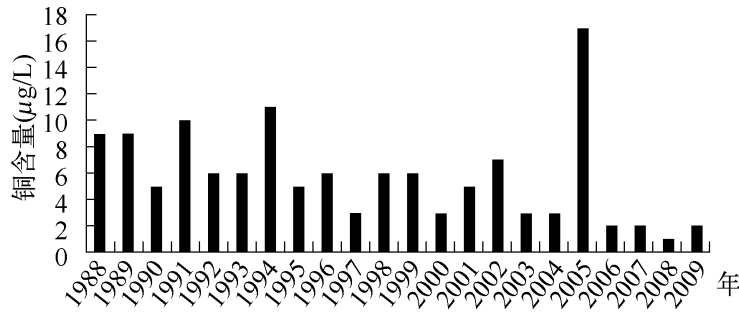

图 4 兴凯湖水体铜含量年际变化

Fig. 4 Interannual varitey of copper contents in Lake Xingkai

表 1 俄方兴凯湖监测结果统计 (2005-2009 年)

Tab. 1 Russian monitoring data of water quality in Lake Xingkai (2005-2009)

\begin{tabular}{cccccc}
\hline 监测项目 & 2005 年 & 2006 年 & 2007 年 & 2008 年 & 2009 年 \\
\hline 悬浮物 $(\mathrm{mg} / \mathrm{L})$ & 52.5 & 39.7 & 19.1 & 31.4 & 29.0 \\
矿化物 $(\mathrm{mg} / \mathrm{L})$ & 113.3 & 100.3 & 102.9 & 111.3 & 110.8 \\
$\mathrm{COD}_{\mathrm{Mn}}(\mathrm{mg} / \mathrm{L})$ & 13.8 & 13.9 & 16.2 & 12.4 & 11.5 \\
$\mathrm{BOD}_{5}(\mathrm{mg} / \mathrm{L})$ & 2.05 & 1.87 & 1.92 & 2.35 & 1.58 \\
氨氮 $(\mathrm{mg} / \mathrm{L})$ & 0.18 & 0.23 & 0.33 & 0.19 & 0.17 \\
亚硝酸盐氮 $(\mathrm{mg} / \mathrm{L})$ & 0.004 & 0.005 & 0.013 & 0.025 & 0.032 \\
硝酸盐氮 $(\mathrm{mg} / \mathrm{L})$ & 0.08 & 0.04 & 0.01 & 0.02 & 0.05 \\
总磷 $(\mathrm{mg} / \mathrm{L})$ & 0.046 & 0.171 & 0.178 & 0.243 & 0.266 \\
铜 $(\mathrm{mg} / \mathrm{L})$ & 0.017 & 0.002 & 0.002 & 0.001 & 0.002 \\
锌 $(\mathrm{mg} / \mathrm{L})$ & 0.042 & 0.045 & 0.039 & 0.020 & 0.016 \\
铝 $(\mathrm{mg} / \mathrm{L})$ & 0.128 & 0.076 & 0.049 & 0.101 & 0.339 \\
锰 $(\mathrm{mg} / \mathrm{L})$ & 0.043 & 0.018 & 0.015 & 0.031 & 0.045 \\
石油类 $(\mathrm{mg} / \mathrm{L})$ & 0.08 & 0.05 & 0.02 & 0.07 & 0.01 \\
阴离子表面 & 0.003 & 0.005 & 0.002 & 0.000 & 0.000 \\
活性剂 $(\mathrm{mg} / \mathrm{L})$ & & & & & \\
氟化物 $(\mathrm{mg} / \mathrm{L})$ & 0.32 & 0.23 & 0.31 & 0.34 & 0.42 \\
挥发酚 $(\mathrm{mg} / \mathrm{L})$ & 0.001 & 0.001 & 0.001 & 0.001 & 0.001 \\
$\mathrm{DDT}$ 及其系列 & 0.012 & 0.008 & 0.001 & 0.005 & 0.002 \\
降解物 $(\mu \mathrm{g} / \mathrm{L})$ & & & & & \\
$\alpha-$ 六氯环 & 0.001 & 0.001 & 0.000 & 0.001 & 0.000 \\
己烷 $(\mu \mathrm{g} / \mathrm{L})$ & & & & & \\
$\gamma-$ 六氯 $\mathrm{x}$ 环 & 0.002 & 0.001 & 0.000 & 0.000 & 0.000 \\
己烷 $(\mu \mathrm{g} / \mathrm{L})$ & & & & & \\
\hline
\end{tabular}
平洋地理研究所对兴凯湖鱼类和雁鸭类肌肉 组织和肝脏进行了杀虫剂含量化验, $30 \%$ 的鱼体样本,特别是其肝和脂肪中有高浓度六氯化苯、DDT 等有机 氯农药成分, 其中鳙 (Aristichthys nobilis)、鲤 (Cyprinus carpio) 和趐嘴红鲌 (Erythroculter ilishaeformis) 体内富 集量最大. 在雁鸭类肝脏和脂肪中发现 DDT 大量残留. 1991 年滨海边疆区环境监测中心对狗鱼 (Esox reicherti)、乌鳢 (Channa argus)、黄滪 (Pelteobagrus fuvidrco) 等 6 种鱼进行生物化学研究, 在所有样品的肝脏和 肌肉中都发现有机氯农药成分. 俄兴凯湖国家监测站 2005 年监测结果显示, 兴凯湖水体高毒有机氯杀虫剂 浓度增加, 在大兴凯湖和松阿察河一年中发生的 7 起有机氯农药高污染事件中, 有 5 起是急性中毒. 2007 年 在大兴凯湖北岸第二泄洪闸的石堤表面发现厚厚绿藻覆盖, 水中的绿藻成团、成片浮荡, 近岸湖水浑浊、粘 稠, 东侧湖滨浴场已无法使用. 兴凯湖农场 21 队附近、八里洼地区近岸水面也出现大量水藻. 小兴凯湖南岸 
表 $21998-2008$ 年兴凯湖水文一生物指标特性

Tab. 2 Characteristics of hydrology-biological indicators of Lake Xingkai from 1998 to 2008

\begin{tabular}{|c|c|}
\hline 指标名称 & 水文生物指标特性 \\
\hline $\begin{array}{l}\text { 浮游动物 } \\
\text { 浮游植物 } \\
\text { 底栖动物 }\end{array}$ & $\begin{array}{l}\text { 发现原生类、轮虫类, 优势种为桡足类、枝角类, 污染指数 } 2.2-2.4 \text {, 水质级别为中度污染 (II-III 类). } \\
\text { 种类少、数量少, 发现硅藻类、黄藻门、蓝藻门、眼虫藻门, 污染指标属 } \beta \text { 附生生物带, 水质级别为中度污染. } \\
\text { 种群有寡毛类、摇蚊幼虫、蜉蝣虫 ( } 2 \text { 种)、甲壳类 ( } 2 \text { 种)、软体动物 ( } 2 \text { 种)、石蛾, 生物污染指数 } 4 \text {, 水质级别 } \\
\text { 为中度污染. }\end{array}$ \\
\hline
\end{tabular}

新开流以西水面形成 $3.5 \mathrm{~km}$ 长绿藻带, 北岸 857 农场及小湖北角 “百米闸” 附近, 春季常发生劣 V 类农田封 闭水退水毒死鱼类现象. 以上情况说明兴凯湖水域有机污染物的生物体富集加剧.

\section{4 兴凯湖流域污染源分析}

兴凯湖污染源主要有穆棱河水带来的城市生活污染源、农业面污染源 (水土流失和稻田水)、工业污染 源、旅游业污染源. 在俄方兴凯湖区主要污染源为前 3 种,其中农业污染源影响最大.

\section{1 点源污染}

主要是穆棱河沿岸城市生活污染、工业污染, 湖区的兴凯湖造纸厂以及近兴凯湖水产养殖场的废水. 穆 棱河流域 3 个大的城市污染源为穆棱市、鸡西市和密山市, 主要污染行业有采矿、热电、洗煤、焦化厂、啤酒 厂等. 城市生活污水排放总量为 $5674 \times 10^{4} \mathrm{t} / \mathrm{a}$, 处理率为 $32.3 \%$; 工业废水 $4092 \times 10^{4} \mathrm{t} / \mathrm{a}$, 处理率为 $96 \%$, 各 企业排放废水虽然经过处理,但仍有超标排放和偷排现象. $\mathrm{COD}_{\mathrm{Mn}} 、 \mathrm{BOD}_{5}$ 、悬浮物、挥发酚等值均较高, 平均 每年泄人湖区东北泡子湿地 $9.53 \times 10^{8} \mathrm{~m}^{3}$ 水中 $\mathrm{COD}_{\mathrm{Mn}}$ 污染物为 $7481 \mathrm{t} 、 \mathrm{BOD}_{5} 2295 \mathrm{t}$ 、硝酸盐氮 $179 \mathrm{t}$. 湖区内的 兴凯湖造纸厂位于小兴凯湖东北部, 排放污水 $300 \times 10^{4} \mathrm{t} / \mathrm{a}$, 每年近 $4750 \mathrm{t}$ 的 COD 污染物通过周边湿地人松 阿察河, 在洪涝季节污染物涌人湖中, 对湖泊水体造成较大威胁. 靠近小兴凯湖北岸边 2000 人常住人口的 水产养殖场, 有 2.7 万只饲养貂貉狐等毛皮动物, 生产、生活污水直排人小兴凯湖, 导致近湖局部水域污染.

表 3 穆棱河水质监测项目最大值 $(2007-2009$ 年)

Tab. 3 The maximum monitoring data of water quality in Muling River (2007 - 2009)

\begin{tabular}{cccc}
\hline 监测项目 & 2007 年 & 2008 年 & 2009 年 \\
\hline $\mathrm{pH}$ & 8.38 & 8.39 & 8.92 \\
悬浮物 $(\mathrm{mg} / \mathrm{L})$ & 887 & 665 & 1440 \\
总硬度 $(\mathrm{mg} / \mathrm{L})$ & 118.98 & 142.00 & 162.00 \\
溶解氧 $(\mathrm{mg} / \mathrm{L})$ & 12.74 & 11.40 & 9.40 \\
$\mathrm{COD}_{\mathrm{Mn}}(\mathrm{mg} / \mathrm{L})$ & 16.70 & 16.60 & 14.10 \\
$\mathrm{BOD}_{5}(\mathrm{mg} / \mathrm{L})$ & 5.20 & 8.90 & 4.90 \\
氨氮 $(\mathrm{mg} / \mathrm{L})$ & 3.45 & 5.59 & 6.85 \\
亚硝酸盐氮 $(\mathrm{mg} / \mathrm{L})$ & 0.628 & 0.287 & 0.278 \\
硝酸盐氮 $(\mathrm{mg} / \mathrm{L})$ & 2.29 & 2.68 & 2.43 \\
挥发酚 $(\mathrm{mg} / \mathrm{L})$ & 0.053 & 0.150 & 0.060 \\
石油类 $(\mathrm{mg} / \mathrm{L})$ & 0.59 & 0.58 & 0.41 \\
\hline
\end{tabular}

穆棱河在 1990s 未受到严重污染, 鸡西市至虎林 市河段为 $\mathrm{IV}-\mathrm{V}$ 类水体 ${ }^{[10]}$, 近 3 年的监测数据表明河 水污染仍然很重 (表 3). 2009 年鸡西市环境监测站 数据显示, 在穆棱河人鸡西段水体监测的各项污染 物中, $\mathrm{COD}_{\mathrm{Mn}}$ 超标率为 $73.4 \%$, 氨氮超标率为 $42.2 \%$, 其次为悬浮物 (超标率 $40.6 \%$ ) 、亚硝酸盐氮 ( 超标 率 $23.4 \%$ )、 $\mathrm{BOD}_{5}$ ( 超标率 $20.3 \%$ )、挥发酚 (超标率 $6.25 \%$ ) 和石油类 (超标率 $6.25 \%$ ).

\section{2 面源污染}

除了穆棱河流域的农田废水外, 沿湖主要是农 业化肥、农药残留以及渔船油污污染. 与十年前相 比,农田化肥施用量增加了一倍, 达 $4.5 \mathrm{t} / \mathrm{km}^{2}$. 湖区 耕地面积 $1486 \mathrm{~km}^{2}$, 每年施用化肥 $21140 \mathrm{t}$, 化肥流失 率 35\%, 流失量 $7400 \mathrm{t}$, 其中氮肥 $3140 \mathrm{t}$, 磷肥 $2250 \mathrm{t}$. 据计算, 每年经小兴凯湖进人大兴凯湖的农田化肥

残留量总磷为 $5.4 \mathrm{t}$, 总氮为 7.6 . 湖区每年施用 $320 \mathrm{t}$ 高残毒除草剂和杀虫剂威胁水环境健康和生物多样性. 这部分污染物进人河泡, 最后汇人大兴凯湖. 化肥、农药是河流、湖泊的隐形杀手, 有近 $70 \%$ 的化肥通过渗透 或被雨水冲刷进人河流湖泊, 农田水中氮、磷、钾含量明显增高, 成为水体富营养化的主要因素, 为藻类生长 提供营养. 小兴凯湖属于大型浅水湖泊, 由 $1990 \mathrm{~s}$ 的贫营养湖泊过渡到中营养湖泊, 并有富营养化倾向. 此 外, 兴凯湖水产捕捞和船只对水体也造成污染, 大、小兴凯湖及周边水域共有柴油机动渔船 330 多只, 每年 $420 \mathrm{t}$ 柴油中向湖水排放 7.4t $\mathrm{SO}_{2}$. 在大、小兴凯湖水面行驶的渔船功率大, 有些 “年龄” 老化严重, 无污控设 
备和环保配套设施,燃油及废油跑冒滴漏,污染水面.

最近几年随着兴凯湖旅游业兴起, 湖区旅游人数每年以 $5 \%$ 的速度递增, 2008 年旅游人数 88 万人/次, 旅游业产生废水 $44 \times 10^{4} \mathrm{t}$ (7-9 月旅游期). 在大、小兴凯湖之间的湖岗有不同规模宾馆、饭店 60 多家以及 当地常住居民 760 多人,每年产生未经处理废水 $75000 t$, 直接排向两湖,成为环湖水质下降直接原因. 在小兴 凯湖北岸、白泡子乡及湖西当壁镇旅游景区,宾馆饭店增多成为新的不可忽视的污染因素.

\section{3 流域生态保护现状}

在兴凯湖污染加剧的同时, 流域内生态保护状况不容乐观. 穆棱河河床两侧草甸、湿地开剭, 行洪滩地 被占, 堤防加高、洪水渲泄和调蓄空间缩小, 洪泛高风险区植被破坏加速了水土流失、污染及水旱灾害发生. 穆棱河水还输人大量泥沙, 年输沙量 $27.9 \times 10^{4} \mathrm{t}$, 与 20 世纪七、八十年代相比, 小兴凯湖湖床抬高 $0.28-$ $0.36 \mathrm{~m}$,湖水变浅. 穆棱河流域内工业化、城市化和农业现代化用水量和废污水排放量在相应增加,沿河城市 大型污染水处理厂均未建成投产, 兴凯湖流域的污水处理能力严重不足. 湖区从农田通向大兴凯湖的排灌 渠 9 条,通向小兴凯湖的有 4 条,从这些灌渠直排农田废水直接污染湖泊.

虽然中俄两国在兴凯湖周围都建立了国家级自然保护区, 但是保护区核心区零散和面积不足 ${ }^{[16]}$ 以及大 兴凯湖周边保护地带过窄 ${ }^{[17]}$ 等弱点对湖泊水环境及生物多样性保护构成威胁. 从 $1990 \mathrm{~s}$ 初开始, 特别是在 黑龙江省政府“五荒”拍卖中后期,保护区天然湿地减少 $260 \mathrm{~km}^{2}$,占其总面积 $11.7 \%$,这些被旺湿地位于保 护区湖岗北核心区、东北泡子核心区穆兴东、西堤边缘以及实验区松阿察河流域 ${ }^{[18]}$. 兴凯湖西部湖岗以北有 长 $27 \mathrm{~km}$ 、宽 $500 \mathrm{~m}$ 的环湖带天然湿地, 发育广泛,水草茂盛, 近 10 年围垦面积达 $8.6 \mathrm{~km}^{2}$, 导致通过环湖湿地 的 5 条农田水渠污水直排向大兴凯湖, 造成近渠局部水域水质降到 $I V$ 类. 东北泡子沼泽湿地是小兴凯湖水 安全的“天然屏障”,从 1998 年以来周边 $85.4 \mathrm{~km}^{2}$ 天然湿地被开垦,边缘地区“涸泽而渔”及蚌食现象仍有发 生,使其蓄洪防旱、净化污水的生态功能达到临界阈值. 被称为跨界 “生态走廊” 的边界河一一松阿察河流域 开旺数量最多, 达 $146 \mathrm{~km}^{2}$. 小兴凯湖及松阿察河流域有 $87.5 \mathrm{~km}^{2}$ 面积苇地, 缺乏科学经营管理, 大部分地区 芦苇覆盖度不大、长势不齐、产量不稳定. 兴凯湖农场和 856 农场境内生态林地面积较大, 但半数以上幼林 稀疏、树木幼小、杂草丛生.

根据目前农田用水现状,每年需从兴凯湖提水 $5.04 \times 10^{8} \mathrm{~m}^{3}$, 俄方一侧农田灌溉面积用水 $7.11 \times 10^{8} \mathrm{~m}^{3}$, 工业与生活用水 $0.5 \times 10^{8} \mathrm{~m}^{3[13]}$, 则近期年用水总量约为 $26.09 \times 10^{8} \mathrm{~m}^{3}$, 所以说兴凯湖水不像大家普遍认为 的非常丰富. 湖区传统粗放型灌溉农业用水, 灌溉水利用系数仅 $0.45-0.50$, 过低价或无偿地使用水资源方 式不利于水资源配置和水环境保护.

兴凯湖地区管理层面多,体制、政策各异, 部门、利益交叉重叠, 缺乏协调交流机制 ${ }^{[19]}$. 多部门、多级管理 体制导致职责不明、各自为政、协调困难. 保护区与社区行政单位之间关系紧张,保护区部分界线不清. 这种 管理上的缺位使得水环境保护及污染防治工作进展缓慢.

\section{5 湖泊保护建议}

兴凯湖水质与年际间水量呈反比关系, 但点、面源污染对水质产生长期而严重影响, 失去 “生态屏障” 保 护的水域危险系数加大. 天然湿地面积萎缩, 湖滨带生态系统受损, 富营养化显现, 生物多样性减少, 水环境 安全形势严峻. 治理浅水湖泊困难远比深水湖泊大、水环境恢复所需时间也长. 大兴凯湖虽然是三江平原最 洁净水体, 但作为乌苏里江源头、国家级自然保护区,水质应定位为 I 类水质. 渔业安全、生态农业、生态旅 游业建设对水环境提出了相应的高标要求. 根据兴凯湖污染现状和存在威胁, 在兴凯湖水体污染及富营养 化防治上, 为了实现治标治本、治水与治污相结合的流域综合管理目标, 需要采取工程和管理措施相结合的 方法,控制污染源和修复生态系统,其可行性措施主要有:

(1) 构建水污染综合防控体系. 流域河湖周边退耕还林、还草、还湿, 恢复植被. 城市及污染企业建设污 水处理厂, 达标排放, 提倡废水资源化利用. 积极推广有机生态农业, 减少农药化肥施用; 发挥水利工程提引 蓄综合功能,节约用水, 控制农田水回流. 修建新水库, 小型水库扩容. 湖泡中培植芦苇、荷花、狭叶香蒲、凤 眼莲等水生环保植物; 定期向小兴凯湖投放鲇、鲢等鱼控制藻类生长; 利用浮游动植物, 底栖动物及水生植 物等天然鱼饵发展生态渔业; 减少渔船直接排污, 逐步推广 “手摇船” 捕捞方式. 固体垃圾集中收集、运出湖 
区. 此外, 在经营管理上, 促进芦苇种植产业化, 提高芦苇产品附加值. 征收水费与污水费, 建立生态补偿机 制. 俄方应扩大保护区面积,重点加强农业面源污染治理.

(2) 建立健全流域水环境及湿地监测预警体系. 加强国家支持的环境、湿地、水文等监测站建设, 长期 监测工业污染、农田退水等的氮、磷浓度及年度排污总量. 建立湿地资源信息管理数据库, 掌握人类活动对 湿地的影响程度. 在中俄跨界联合监测的基础上, 开展湖泊生态环境保护与资源利用的科学研究, 加强重点 领域的技术支撑与工程示范.

(3) 建立高效流域协调、管理体制. 强化整体流域管理, 统一规划环境保护与资源开发. 在《中俄政府兴 凯湖保护区协定》(1996 年) 的框架下, 发挥中俄兴凯湖混合委员会作用, 从更高层面、多方位地协调兴凯湖 区域保护与开发问题. 国家应将其纳人《松花江流域水污染防治规划》范围. 地方政府应确立流域综合治理 规划和污染防治责任目标, 同时提高公众参与度, 在政府、居民、农民及企业间搭建合作平台, 加大投资, 加 强污染治理的执法、宣教等工作,形成监督、管治水体资源和环境的合力.

致谢: 密山市环保局扈大明副局长、鸡西市环境监测中心站潘斌全站长以及中国科学院东北地理与农业生 态研究所姜明博士在搜集材料和文章撰写过程中给予了指导和帮助.

\section{6 参考文献}

[1] 李世杰,窦鸿身,舒金华等. 我国湖泊水环境问题与水生态系统修复的探讨. 中国水利,2006,13:14-17.

[2] 朱广伟. 太湖富营养化现状及原因分析. 湖泊科学,2008,20(1):21-26.

[ 3 ] 严承高,袁 军. 试论三江平原及其生物多样性的国际意义与保护对策. 林业资源管理, 1997, (1) :35-39.

[ 4 ] 刘景瑞. 三江平原资源与生态水利用的实施探讨. 水利水电科技进展, 2002,22(6) :27-29,38.

[ 5 ] 李晓民等. 黑龙江流域湿地及保护. 哈尔滨: 东北林业大学出版社,2005.

[ 6 ] Глущенко ЮН, ШибаевЮВ. Ханкайский заповедник нуждается в расширении территории. Птицы пресных вод и морских побережий юга дальнего востока Росии и их охраны, Владивосток, Дальнаука, 1996:76-85.

[ 7 ] 王艳丽, 艾晓燕, 韩守江. 三江平原水资源开发利用存在的问题与可持续利用对策探讨. 哈尔滨师范大学学报 (自 然科学版) ,2008,24(5): $95-97$.

[ 8 ] Водно-болотные угодья России, том №5, Водно-болотные угодья юга Дальнего Востока России, под общей редакцией, Бочариникова ВН, Москва, $2005: 91-100$.

[ 9 ] 姬忠光,吴明官. 国境界湖兴凯湖水资源可利用量初探. 黑龙江水利科技, 2006,34(2):47-49.

[10] 孙 冬, 孙晓俊. 兴凯湖水文特性. 东北水利水电, 2006,261(4):21,27.

[11] http://www. answers. com/topic/khanka-lake.

[12] 密山县志. 北京: 中国标准出版社, $1994: 189$.

[13] 刘正茂,吕宪国,武海涛等. 兴凯湖最低生态安全水位研究. 水利水电技术, $2008,(2): 8-10,25$.

[14] 卢 玲,刘 永,赵彩霞等. 黑龙江绥芬河兴凯湖渔业水域水质及评价. 水产学杂志, 2002,15(2):69-73.

[15] Семыкина ГИ. Обзор состояния и загрязнения озера Ханка по материалам Государственной сети наблюдений за загрязнением окружающей среды. Проблемы сохранения водно-болотных угодий международного значения: Озеро Ханка: Тр. Второй международной научно-практической конференции, Владивосток, 2006 :190-200.

[16] Морозов ВЛ, Белый ЕА. Лугово-болотные резерваты и экологический кризис вб ассейне озера Ханка. Проблемы сохранения водно-болотных угодий международного значения: Озеро Ханка: Тр. Международной научно-практической конференции, Спасск-Дальний, 1995 :30-34.

[17] Герштейн ВВ. Видовой состав рыб заповедника 《Ханкайский》и его охранной зоны. Проблемы сохранения водно-болотных угодий международного значения: Озеро Ханка: Тр. Второй международной научнопрактической конференции, Владивосток, 2006:57-66.

[18] 奕晓枫, 李朝辉. 兴凯湖国家级自然保护区现状. 动物学杂志, 1999,33(4):26-27.

[19] 王献溥, 于顺利,刘振杰. 黑龙江省兴凯湖保护区的基本特点及其有效管理. 野生动物杂志,2006,(2) :29-32. 